\title{
dsDNA from extracellular vesicles (EVs) in adult AML
}

\author{
Simona Bernardi ${ }^{1,2}$ (D) $\cdot$ C. Zanaglio $^{1,2} \cdot$ M. Farina $^{1} \cdot$ N. Polverelli ${ }^{1} \cdot$ M. Malagola $^{1} \cdot$ D. Russo $^{1}$
}

Received: 6 May 2020 / Accepted: 27 May 2020 / Published online: 30 May 2020

(C) The Author(s) 2020

Dear Editor,

We read with great interest the article by Kontopoulou et al. [1] describing the study of the dsDNA carried by extracellular vesicles (EVs) in pediatric acute myeloid leukemia (AML) patients. The authors described a superimposable mutational status between dsDNA extracted from EVs isolated in patients' plasma and dsDNA extracted from primary leukemia cells. Moreover, they observed a decreasing number of EVs in patients undergoing treatment.

EVs, in particular exosomes, lately attracted a considerable interest in cancer research [2] and several data are suggesting that they play an important role also in the onco-hematologic field [3]: first, because they carry out important disease markers for leukemogenesis understanding $[4,5]$, second because of their diagnostic potential [6], and last, but not least, for the monitoring of the minimal residual disease [7].

We have previously demonstrated the feasibility of the leukemia-derived exosomes enrichment by an immunoselection system in chronic myeloid leukemia patients [7, 8]. Then, we explored the feasibility of this approach also in adult AML patients. We enrolled 7 AML patients and 1 healthy control (Table 1) and collected peripheral blood (PB) and bone marrow (BM) specimens from AML patients, while only PB was collected from healthy donor. Exosomes were isolated from $1 \mathrm{ml}$ of plasma by SeleCTEVTM Enrichment kit (Exosomics Siena SpA). The kit allows the direct exosomal DNA (exoDNA) extraction and the isolation is based on a proprietary peptide

Simona Bernardi

simonabernardi86@gmail.com; simona.bernardi@unibs.it

1 Unit of Blood Diseases and Stem Cell Transplantation, Department of Clinical and Experimental Sciences, ASST Spedali Civili di Brescia, University of Brescia, 25123 Brescia, Italy

2 CREA Laboratory (Centro di Ricerca Emato-Oncologica AIL), ASST Spedali Civili di Brescia, 25123 Brescia, Italy affinity method. We isolated also PB and BM cells from all samples and performed a manually genomic DNA extraction by a commercial kit (Qiagen). Genomic DNA and exoDNA were then sequenced by next-generation sequencing (NGS) using a custom gene panel (Nimblegen, Roche Diagnostics). The sequencing run was performed on MiniSeq platform (Illumina).

We first quantified the dsDNA extracted from circulating exosomes and observed that exoDNA quantity was consistent with the leukemic burden. In particular, the lowest quantity of exoDNA was isolated in case 7 presenting complete remission (CR) before allo-stem cell transplantation (allo-SCT), while the highest quantity of exoDNA was isolated in case 5 presenting relapse. By NGS analysis, in 5 out of 7 (71\%) AML cases, we identified leukemia-specific mutations on exoDNA. They were confirmed on PB and BM genomic DNA in 4/5 cases $(80 \%)$. In one case (case 2) $(20 \%)$, the mutations were confirmed only on BM genomic DNA. In 2/7 (29\%) AML cases, no leukemia-specific mutation was sequenced neither on exoDNA nor on PB and BM genomic DNA (Table 1). No pathologic variant was sequenced on healthy control DNA samples.

These results confirm the evidence reported by Kontopoulou et al. [1] in pediatric AML and extend the presence of the same phenomenon to adult cases of AML. In particular, Kontopoulou and colleagues reported a decrease in EV numbers in patients after treatment compared with initial diagnosis, while we experienced a decrease in exoDNA quantity in patients presenting therapy response or CR.

Altogether, these data uncover the role of leukemia-derived exosomes as active carriers of leukemia cell markers and the opportunity to consider the enrichment and study of exoDNA an additional diagnostic tool for a less invasive and more personalized management of both adult and pediatric AML patients. This is of pivotal importance in the so-called $4 \mathrm{P}$ medicine era $[9,10]$, even if it has to be confirmed on larger cohorts of patients and explored in other leukemias. 
Table 1 Clinical and biological features of AML cases and healthy control

\begin{tabular}{|c|c|c|c|c|c|c|c|c|}
\hline & Case 1 & Case 2 & Case 3 & Case 4 & Case 5 & Case 6 & Case 7 & Healthy control \\
\hline Sex & M & $\mathrm{F}$ & $\mathrm{F}$ & M & F & $\mathrm{F}$ & $\mathrm{F}$ & M \\
\hline Age & $61 \mathrm{y}$ & $47 \mathrm{y}$ & $30 \mathrm{y}$ & $71 \mathrm{y}$ & $44 \mathrm{y}$ & $64 \mathrm{y}$ & $44 \mathrm{y}$ & $45 \mathrm{y}$ \\
\hline Disease status & Diagnosis & Relapse & $\begin{array}{l}\text { CR (3 m post } \\
\text { allo-SCT) }\end{array}$ & $\begin{array}{l}\text { Diagnosis (AML } \\
\text { post MDS) }\end{array}$ & Relapse & $\begin{array}{l}\text { Relapse (post } \\
\text { allo-SCT) }\end{array}$ & CR (pre allo-SCT) & $\begin{array}{l}\text { Healthy, with } \\
\text { no tumor } \\
\text { history }\end{array}$ \\
\hline $\begin{array}{l}\text { MRD in BM } \\
\text { (blast \%) }\end{array}$ & $76 \%$ & $65 \%$ & $0 \%$ & $77 \%$ & $79 \%$ & $29 \%$ & $0 \%$ & n.a. \\
\hline ExoDNA quantity & $13.4 \mathrm{ng} / \mathrm{ul}$ & $10.1 \mathrm{ng} / \mathrm{ul}$ & $6.3 \mathrm{ng} / \mathrm{ul}$ & $16.3 \mathrm{ng} / \mathrm{ul}$ & $16.6 \mathrm{ng} / \mathrm{ul}$ & $9.3 \mathrm{ng} / \mathrm{ul}$ & $4.6 \mathrm{ng} / \mathrm{ul}$ & $6.2 \mathrm{ng} / \mathrm{ul}$ \\
\hline $\begin{array}{l}\text { Mutation on } \\
\text { exoDNA (nr) }\end{array}$ & 4 & 5 & 0 & 3 & 4 & 4 & 0 & 0 \\
\hline $\begin{array}{l}\text { Mutation on PB } \\
\text { DNA (nr) }\end{array}$ & 4 & 3 & 0 & 3 & 4 & 4 & 0 & 0 \\
\hline $\begin{array}{l}\text { Mutation on BM } \\
\text { DNA (nr) }\end{array}$ & 4 & 5 & 0 & 3 & 4 & 4 & 0 & n.a. \\
\hline
\end{tabular}

$M$, male; $F$, female; $y$, years old; $m$, months; allo-SCT, allogeneic stem cell transplantation; $M D S$, myelodysplastic syndrome; $C R$, complete remission; $B M$, bone marrow; n.a., not applicable

Authors' contribution SB, CZ, and DR designed the study; SB and $\mathrm{CZ}$ performed the exosomes isolation and NGS analysis; SB, CZ, MF, NP, $\mathrm{MM}$, and DR collected and analyzed the data; $\mathrm{SB}, \mathrm{CZ}, \mathrm{MF}$, and DR wrote the paper; all authors gave their final approval before submission.

Data availability Data are available by the corresponding author upon request.

\section{Compliance with ethical standards}

Conflict of interest The authors declare that they have no conflict of interest.

Ethical approval All procedures performed in studies involving human participants were in accordance with the ethical standards of the institutional and/or national research committee and with the 1964 Helsinki declaration and its later amendments or comparable ethical standards.

Informed consent Informed consent was obtained from all individual participants included in the study.

Open Access This article is licensed under a Creative Commons Attribution 4.0 International License, which permits use, sharing, adaptation, distribution and reproduction in any medium or format, as long as you give appropriate credit to the original author(s) and the source, provide a link to the Creative Commons licence, and indicate if changes were made. The images or other third party material in this article are included in the article's Creative Commons licence, unless indicated otherwise in a credit line to the material. If material is not included in the article's Creative Commons licence and your intended use is not permitted by statutory regulation or exceeds the permitted use, you will need to obtain permission directly from the copyright holder. To view a copy of this licence, visit http://creativecommons.org/licenses/by/4.0/.

\section{References}

1. Kontopoulou E, Strachan S, Reinhardt K, Kunz F, Walter C, Walkenfort B, Jastrow H, Hasenberg M, Giebel B, von Neuhoff
N, Reinhardt D, Thakur BK (2020) Evaluation of dsDNA from extracellular vesicles (EVs) in pediatric AML diagnostics. Ann Hematol 99(3):459-475

2. Shi S, Gao Y, Liu M, Bu Y, Wu J, Tian J, Zhang J (2020) Top 100 most-cited articles on exosomes in the field of cancer: a bibliometric analysis and evidence mapping. Clin Exp Med. https://doi.org/10. 1007/s10238-020-00624-5

3. Boyiadzis M, Whiteside TL (2017) The emerging roles of tumorderived exosomes in hematological malignancies. Leukemia 31: 1259-1268 Nat Publ Group

4. Kumar B, Garcia M, Weng L, Jung X, Murakami JL, Hu X, McDonald T, Lin A, Kumar AR, DiGiusto DL, Stein AS, Pullarkat VA, Hui SK, Carlesso N, Kuo YH, Bhatia R, Marcucci G, Chen CC (2018) Acute myeloid leukemia transforms the bone marrow niche into a leukemia-permissive microenvironment through exosome secretion. Leukemia. 32(3):575-587

5. Wierz M, Pierson S, Gargiulo E, Guerin C, Moussay E, Paggetti J (2019) Purification of leukemia-derived exosomes to study microenvironment modulation. Methods Mol Biol 1884:231-245

6. Handschuh L (2019) Not only mutations matter: molecular picture of acute myeloid leukemia emerging from transcriptome studies. J Oncol 2019:1-36

7. Bernardi S, Malagola M, Polverelli N, Russo D (2020) Exosomes in chronic myeloid leukemia: are we reading a new reliable message? Acta Haematol. https://doi.org/10.1159/000505088

8. Bernardi S, Foroni C, Zanaglio C, Re F, Polverelli N, Turra A, Morello E, Farina M, Cattina F, Gandolfi L, Zollner T, Buttini EA, Malagola M, Russo D (2019) Feasibility of tumor-derived exosome enrichment in the onco-hematology leukemic model of chronic myeloid leukemia. Int J Mol Med 44(6):2133-2144

9. Hood L, Friend S (2011) Predictive, personalized, preventive, participatory (P4) cancer medicine. Nat Rev Clin Oncol 8:184-187

10. Morello E, Malagola M, Bernardi S, Pristipino C, Russo D (2018) The role of allogeneic hematopoietic stem cell transplantation in the four P medicine era. Blood Res 53:3-6 Korean Society of Hematology

Publisher's note Springer Nature remains neutral with regard to jurisdictional claims in published maps and institutional affiliations. 